Please do not remove this page

RMIT

UNIVERSITY

\title{
Perovskite-based low-cost and high-efficiency hybrid halide solar cells
}

Fan, Jiandong; Jia, Baohua; Gu, Min

https://researchrepository.rmit.edu.au/esploro/outputs/9921860207101341/filesAndLinks?institution=61RMIT_INST\&index=null

Fan, J., Jia, B., \& Gu, M. (2014). Perovskite-based low-cost and high-efficiency hybrid halide solar cells. Photonics Research, 2(5), 111-120. https://doi.org/10.1364/PRJ.2.000111

Document Version: Published Version

Published Version: https://doi.org/10.1364/PRJ.2.000111

Repository homepage: https://researchrepository.rmit.edu.au

(C) 2014 Chinese Laser Press

Downloaded On 2023/04/26 13:37:03 +1000

Please do not remove this page 
Thank you for downloading this document from the RMIT Research Repository.

The RMIT Research Repository is an open access database showcasing the research outputs of RMIT University researchers.

RMIT Research Repository: http://researchbank.rmit.edu.au/

\section{Citation:}

Fan, J, Jia, B and Gu, M 2014, 'Perovskite-based low-cost and high-efficiency hybrid halide solar cells', Photonics Research, vol. 2, no. 5, pp. 111-120.

See this record in the RMIT Research Repository at:

https://researchbank.rmit.edu.au/view/rmit:34698

Version: Published Version

Copyright Statement:

(C) 2014 Chinese Laser Press

Link to Published Version:

https://dx.doi.org/10.1364/PRJ.2.000111 


\title{
Perovskite-based low-cost and high-efficiency hybrid halide solar cells
}

\author{
Jiandong Fan, Baohua Jia, and Min Gu* \\ Centre for Micro-Photonics, Faculty of Science, Engineering and Technology, Swinburne University of Technology, \\ Hawthorn, Victoria 3122, Australia \\ *Corresponding author:mgu@swin.edu.au
}

Received May 12, 2014; revised July 9, 2014; accepted July 10, 2014;

posted July 16, 2014 (Doc. ID 211989); published August 11, 2014

\begin{abstract}
A cost-effective and high-throughput material named perovskite has proven to be capable of converting $15.9 \%$ of the solar energy to electricity, compared to an efficiency of $3.8 \%$ that was obtained only four years ago. It has already outperformed most of the thin-film solar cell technologies that researchers have been studying for decades. Currently, the architecture of perovskite solar cells has been simplified from the traditional dye-sensitized solar cells to planar-heterojunction solar cells. Recently, the performance of perovskite in solar cells has attracted intensive attention and studies. Foreseeably, many transformative steps will be put forward over the coming few years. In this review, we summarize the recent exciting development in perovskite solar cells, and discuss the fundamental mechanisms of perovskite materials in solar cells and their structural evolution. In addition, future directions and prospects are proposed toward high-efficiency perovskite solar cells for practical applications. (c) 2014 Chinese Laser Press
\end{abstract}

OCIS codes: $\quad$ (040.5350) Photovoltaic; (250.0250) Optoelectronics; (310.0310) Thin films. http://dx.doi.org/10.1364/PRJ.2.000111

\section{INTRODUCTION}

Global energy consumption has been continually increasing with population growth and fast-paced industrial development in recent decades, which demands renewable energy sources in view of long-term sustainable development. Generating cost-effective and environmentally benign renewable energy remains a major challenge for both technological and scientific development [1,2]. Solar cells based on the photovoltaic effect with the advantages of decentralization and sustainability have attracted great attention in the past 50 years. Currently, the photovoltaics market is dominated by crystalline silicon-based solar cells with a share of 89\% [3]; however, they suffer from low cost effectiveness, and they also have the longest energy payback time of commercial photovoltaic technologies [4]. An emerging class of thin-film devices based on amorphous silicon, $\mathrm{Cu}(\mathrm{In}, \mathrm{Ga}) \mathrm{Se}_{2-\mathrm{x}} \mathrm{S}_{\mathrm{x}}$, or CdTe, is beginning to penetrate the market, which makes its headway in terms of processing costs per unit area [5-7]. However, the manufacture of inorganic thin-film solar cells requires high vacuum and high temperature-based techniques [8]. In addition, thin films containing low abundance and toxic elements limit their large-scale production and widespread application [9].

Since their breakthrough in 1991 [10], dye-sensitized solar cells (DSSCs) have attracted considerable attention because of their potential application in low-cost solar energy conversion [11-22]. As a consequence of the significant efforts in DSSC-related research, a high efficiency exceeding $12 \%$ was obtained by using a $10 \mu \mathrm{m}$ mesoporous $\mathrm{TiO}_{2}$ film sensitized with organic dye and cobalt redox electrolyte [23]. Meanwhile, solid-state DSSCs have also been investigated, where the liquid electrolyte was replaced by solid hole-transporting materials [e.g., 2,2',7,7' -tetrakis-(N,N-di-p-methoxyphenyl- amine)-9,9'spirobifluorene (spiro-MeOTAD), poly(3-hexylthiophene) (P3HT), polyaniline, and polypyrrole] in order to both simplify solar cell production and increase the opencircuit voltage and stability of solar cells [24-28]. However, solid-state DSSCs suffer from faster electron recombination dynamics between electrons in the $\mathrm{TiO}_{2}$ and holes in the solid hole transporter [29], which results in the low efficiency of solid-state DSSCs.

Recently, the perovskite sensitizer $\mathrm{ABX}_{3}\left(\mathrm{~A}=\mathrm{CH}_{3} \mathrm{NH}_{3}\right.$, $\mathrm{B}=\mathrm{Pb}, \mathrm{Sn}$, and $\mathrm{X}=\mathrm{Cl}, \mathrm{Br}, \mathrm{I})$ has attracted great attention due to its superb light-harvesting characteristics [30-60]. Moreover, perovskite is composed of inexpensive and earth abundant materials. It is processable at low temperature preferably via the printing techniques. In addition, it generates charges freely in the bulk material after light absorption, which enables low energy-loss charge generation and collection [61-63].

Within a short period from August 2012 to December 2013, the power conversion efficiency (PCE) of perovskite-based solar cells was significantly improved from $7.2 \%$ to $15.9 \%$; the high photo conversion efficiencies of these systems are associated with the comparable optical absorption length and charge-carrier diffusion lengths, transcending the traditional constraints of solution-processed semiconductors [30-60,64], and outperforming most other third-generation thin-film solar cell technologies that have been studied for decades (Fig. 1). This perovskite technology is now compatible with the first- and second-generation technologies, and is hence likely to be adopted by the conventional photovoltaics community and industry. Therefore, it may find its way rapidly into utility-scale power generation if some challenging issues, for example, stability concerns of perovskite photovoltaics, are to be solved effectively [65]. 


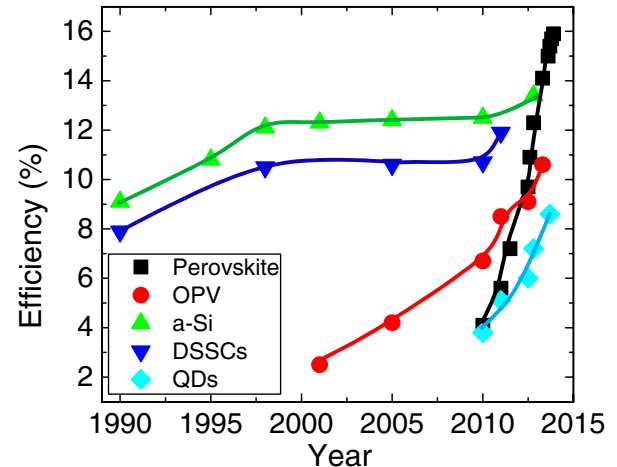

Fig. 1. Efficiency evolution of different thin-film photovoltaic technologies.

While perovskite-based solar cells have been widely studied, there are rare reviews and/or perspective literature published on systematically summarizing the mechanisms for unexpected breakthroughs and rapid evolution in the field of perovskite photovoltaics [66-69]. Herein, we review the recent impressive developments and discuss the properties and working mechanisms of perovskite materials in solar cells. Finally, the prognosis for future progress in exploiting perovskite solar cells is addressed toward high efficiency for applications.

\section{MATERIALS, STRUCTURE, AND PROPERTIES OF PEROVSKITE}

The basic building block of perovskite is the $\mathrm{ABX}_{3}$ perovskite structure (Fig. 2). This simple structure consists of a 3D network corner-sharing $\mathrm{BX}_{6}$ octahedra, where the $\mathrm{A}$ (e.g., $\mathrm{A}=\mathrm{Cs}, \mathrm{CH}_{3} \mathrm{NH}_{3}, \mathrm{NH}_{2} \mathrm{CH}=\mathrm{NH}_{2}$ ) cations are located in the larger 12-fold coordinated hales between the octahedron (Fig. 2) [70]. It is typically composed of a metal cation $(\mathrm{M}=\overline{\mathrm{S}} \mathrm{n}, \overline{\mathrm{Pb}}, \mathrm{Ge}, \mathrm{Cu})$ and its ligantanions $\left(\mathrm{X}=\mathrm{O}^{2-}, \mathrm{Cl}^{-}\right.$, $\mathrm{Br}^{-}, \mathrm{I}^{-}$, or $\left.\mathrm{S}^{2-}\right)$. In the case of inorganic perovskite compounds, the structures can be distorted as a result of the cation displacements, which give rise to the useful properties of ferroelectricity and antiferroelectricity of many perovskite systems due to the stereo chemically active pairs of A cations [71].

In this review, we focus our insight into organic-inorganic hybrid perovskite compounds, which are the most used photoabsorbers in perovskite solar cells. In organic-inorganic hybrid perovskite compounds, the advantages of inorganic components, including the thermal stability and the high degree of the structural order, can be well combined with the interesting characteristics of organic materials, such as the functional versatility, mechanical flexibility, and low-cost processability [72-74]. Organic molecules or polymers and inorganic perovskite can be bundled by different types of bonds. There are numerous reported compounds with covalent bonding between organic and inorganic units [75]. This class of extended organometallic and other covalently interacting compounds, generally containing simple organic radicals, is somewhat limited. The degree of interaction between organic and inorganic species in the Van der Waals interacting systems is relatively small. Obviously the choice of the organic cations is limited because of the restricted dimension of the cuboctahedral hole formed by the 12 nearest-neighbor $\mathrm{X}$ atoms. In fact, the compounds $\mathrm{CH}_{3} \mathrm{NH}_{3} \mathrm{MX}_{3}$, with $\mathrm{M}=\mathrm{Sn}, \mathrm{Pb}$ and $\mathrm{X}=\mathrm{Cl}, \mathrm{Br}$, and $\mathrm{I}$, have been successfully synthesized [76-81]. Each of these systems has a cubic structure at the highest temperature phase. At high temperature the organic cation shows orientational disorder. At lower temperature the cubic phase results in a structural transition due to a tolerance factor smaller than unity. In fact, upon cooling, the structure distorts to lower its symmetry since the motion of the methylammonium cation has more restrictions [82].

Meanwhile, the possibility of merging the properties of typical inorganic crystals with those of molecular organic solids has stimulated intensive research into the versatile properties in the last 15 years. For example, a homologous series of $\left(\mathrm{C}_{4} \mathrm{H}_{9} \mathrm{NH}_{3}\right)_{2}\left(\mathrm{CH}_{3} \mathrm{NH}_{3}\right)_{\mathrm{n}-1} \mathrm{Sn}_{\mathrm{n}} \mathrm{I}_{3 \mathrm{n}+1}$ compounds undergoes a semiconducting $(n<3)$-to-metallic $(n>5)$ transition with increasing $n$. Its end member $(n=\infty)$, cubic perovskite $\mathrm{CH}_{3} \mathrm{NH}_{3} \mathrm{SnI}_{3}$ compound, is claimed to be a low-carrier-density p-type metal $[\underline{83}, \underline{84}]$. Theoretical calculations on perovskite suggested that their electronic properties strongly depend on the structure of the inorganic cage and the formation of the perovskite octahedral network [70]. Varying the organic and inorganic components and the stoichiometric ratio between them, it is possible to modulate the system dimensionality and electronic, magnetic, and optical properties. Moreover, the presence of weak bonds in the perovskite structures guarantees flexibility and malleability that could allow the deposition of thin films on flexible substrates $[\underline{60}, \underline{85}]$.

\section{PEROVSKITE-BASED SOLAR CELLS}

\section{A. Evolution of Perovskite Solar Cells}

As mentioned previously, perovskite-based hybrid halide materials are not new materials, and have been extensively studied because of their useful physical properties, including enhanced exciton binding energies, nonlinear optical properties, electroluminescence, organic-like mobility, magnetic
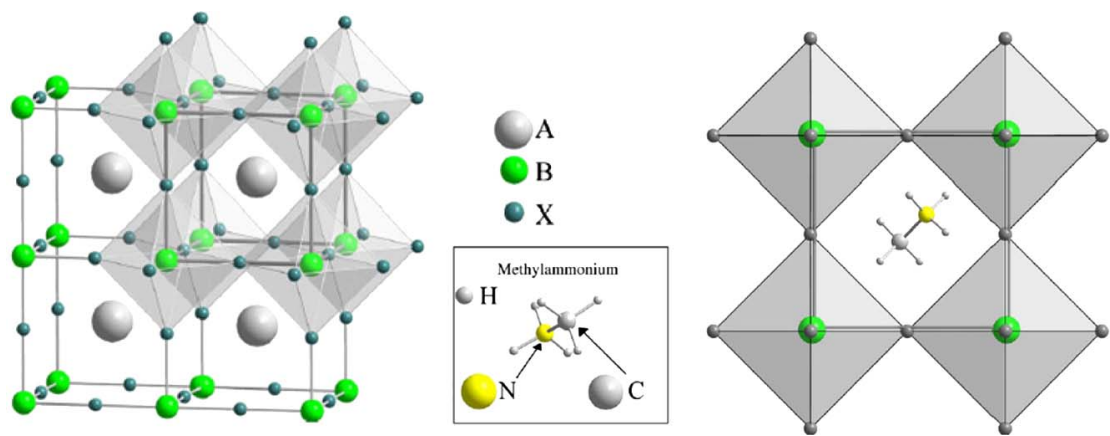

Fig. 2. Unit cell of basic $\mathrm{ABX}_{3}$ perovskite structure. The $\mathrm{BX}_{6}$ corner-sharing octahedra are evidenced. Adapted with permission from Ref. [70]. 
properties, and conductivity [6-1ㅣㅇ. However, perovskite absorbers have emerged into the field of DSSCs since 2009. The first perovskite-sensitized $\mathrm{TiO}_{2}$ solar cell used liquid electrolytes based on iodide and bromide. The corresponding devices gave PCEs of $3.8 \%$ and $3.1 \%$, respectively [30]. In studies of durability, continuous irradiation caused a photocurrent decay for an open cell exposed to air. Later, in 2011, the titania surface and perovskite processing were optimized, which gave a $\mathrm{PCE}$ of $6.5 \%$ with the $\mathrm{CH}_{3} \mathrm{NH}_{3} \mathrm{PbI}_{3}$-based iodide liquid electrolyte solar cell. Again, as was mentioned, the perovskite nanocrystals dissolved/decomposed in the iodide liquid electrolyte, and the solar cell rapidly degraded within a few minutes. In 2012, the liquid electrolyte in a perovskite containing cell was replaced with a solid version, and a PCE of $9.7 \%$ was achieved [31]. In 2013, a sequential deposition method for the formation of the perovskite pigment within the porous metal oxide film was developed. The technique for the fabrication of solid-state mesoscopic solar cells greatly increased the reproducibility of cell performance and allowed a high PCE of $15 \%$. Meanwhile, a simple planar-heterojunction (p-i-n) solar cell incorporating vapor-deposited perovskite as the absorbing layer has been developed, and demonstrated a solar-to-electrical PCE of 15.4\% [32]. At the end of 2013, the architectures of the meso-superstructured solar cell (MSSC) were optimized, and a PCE of up to $15.9 \%$ (short-circuit current density $J_{\mathrm{sc}}=21.5 \mathrm{~mA} / \mathrm{cm}^{2}$, open-circuit voltage $V_{\mathrm{oc}}=1.02 \mathrm{~V}$, and fill factor $\mathrm{FF}=0.71$ ) in an all low temperature processed solar cell was achieved, which was the highest reported efficiency amongst perovskite-based solar cells through the end of 2013 [33]. Table 1 gives a comprehensive summary of the device evolution and performance of perovskite solar cells, including the perovskite materials, deposition methods, photoanodes, active areas, hole-transport materials (HTM), and PCE.

\section{B. Photoanodes}

Figure 3 displays the architecture schematics of three types of photoanodes in perovskite solar cells. Like the architecture of DSSCs, mesoporous metal oxide films [Fig. 3(a)] are usually adopted as the working electrodes in the novel construction of perovskite-based solar cells $[\underline{30,31,39,40,45]}$. It was noticed that the charge extraction rates were significantly faster for the perovskite-sensitized cells in comparison to the conventional DSSCs during the investigation of the charge-transport properties of perovskite-sensitized solar cells [흐]. Inspired by this novel behavior, solar cells with new architectures in

Table 1. Summary of the Device Evolution and Performance of Perovskite Solar Cells

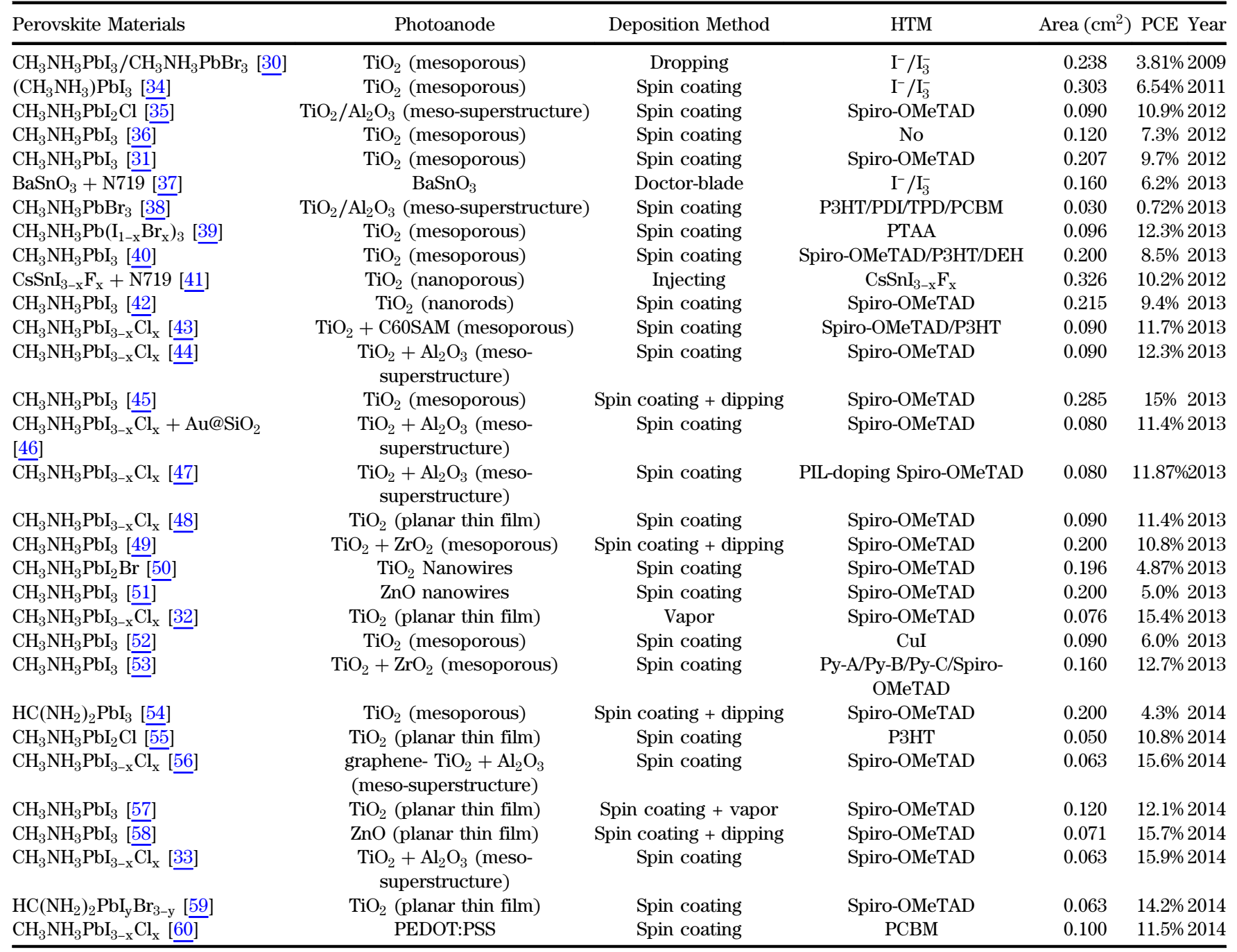






(a)

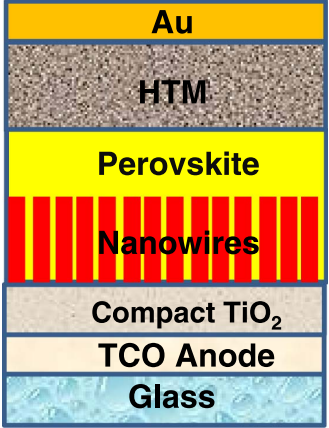

(b)

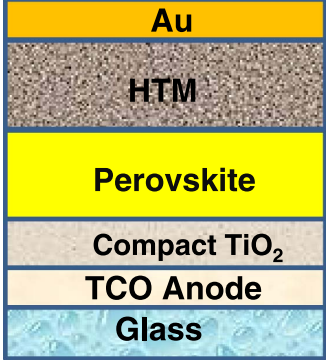

(c)

Fig. 3. Architecture schematics of three types of photoanodes in perovskite solar cells: (a) mesoporous $\mathrm{TiO}_{2} / \mathrm{Al}_{2} \mathrm{O}_{3} / \mathrm{ZrO}_{2}$, (b) $\mathrm{TiO}_{2} / \mathrm{ZnO} \mathrm{NWs}$, and (c) without the scaffold layer.

which the mesoporous $\mathrm{TiO}_{2}$ was replaced by the insulating mesoporous $\mathrm{Al}_{2} \mathrm{O}_{3}$ with a similar meso-morphology were developed. The primary intention was to study and elucidate whether electron transport occurred through the perovskite phase and whether mesoporous $\mathrm{TiO}_{2}$ was required at all [35]. Intriguingly, the PCE of such a MSSC unexpectedly reached $10.9 \%$ with a high $V_{\text {oc }}$ of $0.98 \mathrm{~V}(\sim 0.2-0.3 \mathrm{~V}$ higher compared to the mesoporous $\mathrm{TiO}_{2}$ ), which gives great promise for significant future increases in efficiency. It also suggests the original components of the DSSCs no longer remain. Very recently, the PCE of MSSC based on perovskite has been further improved up to $15.9 \%$ [33].

As addressed previously, mesoporous metal oxide films have been widely adopted as the working electrodes in the novel construction of perovskite-based solar cells. However, the difficulty in pore filling has been a persistent issue in such nanoparticulate films because of their labyrinthine maze structure [92]. In this scenario, a vertically aligned nanowire $(\mathrm{NW})$ /nanotube (NT) structure [Fig. 3(b)] may be another alternative candidate for pore filling of the solid holetransporting materials because of its open porous structure [93-99]. Moreover, vertically aligned NWs/NTs were reported to be better in electron transportation and recombination behaviors than nanoparticulate films in liquid-based DSSCs [100]. Such special structures can effectively improve the charge transport and decrease the electron recombination in solar cells. Apart from the advantages mentioned above, the NWs/NTs form an advantageous framework structure for solar cells with hole conductors presenting faster recombination [24,101]. Considering the excellent absorption proprieties of perovskite, a possible decrease of the total surface area of the NWs/NTs compared to the nanoparticles may not provoke a significant deterioration of the photocurrent. In contrast, better distribution of the materials in the semiconductor structure can play a determining role in the enhancement of the photo-charge generation. $\mathrm{ZnO} \mathrm{NW}$ arrays have been employed as photoanodes in perovskite solar cells [51]. It was demonstrated that $\mathrm{ZnO} \mathrm{NWs}$ offer a fast electron transport pathway and the electron transportation time in the $\mathrm{ZnO}$ nanorods was slightly shorter than in mesoporous $\mathrm{TiO}_{2}$ films with a similar thickness. The optimized solar cell exhibited an efficiency of $5.0 \%$. $\mathrm{TiO}_{2} \mathrm{NWs}$ have also been used as photoanodes in perovskite solar cells $[\underline{42,50]}$. Infiltration of perovskite-adsorbed submicrometer-thick rutile $\mathrm{TiO}_{2} \mathrm{NWs}$ with spiro-MeOTAD yielded a strikingly high PCE of $9.4 \%$. Since comparative studies on photovoltaic behavior and performance between anatase and rutile $\mathrm{TiO}_{2} \mathrm{NWs}$ are expected to provide more advanced information, attempts to fabricate and study solid-state perovskite-sensitized solar cells based on well-defined anatase $\mathrm{TiO}_{2} \mathrm{NWs}$ are underway [42].

All of the work has demonstrated that perovskite semiconductors can exhibit sufficiently good ambipolar charge transport and the principal roles of photovoltaic operation including light absorption, charge generation, and transport of both electrons and holes. Moreover, the perovskite absorber is capable of operating in a much simpler planar architecture. As an ultimate demonstration of ambipolar transport, p-i-n perovskite solar cells with an extremely high efficiency over $15 \%$ are constructed, which experimentally suggest that nanostructuring is not necessary to achieve high efficiencies with perovskite [32]. Simplified perovskite solar cells with a planar thin-film "p-i-n" architecture have been demonstrated, as shown in Fig. 3(c). $\mathrm{TiO}_{2}$ and $\mathrm{ZnO}$ p-i-n structures were employed to obtain PCEs of $12.1 \%$ and $15.7 \%$, respectively $[57,58]$. But it remains challenging to determine whether meso-structure is essential for the highest efficiencies, or whether the thin-film p-i-n can lead to a superior technology.

\section{Perovskite Thin Films}

Recently, methylammonium lead halide $\left(\mathrm{CH}_{3} \mathrm{NH}_{3} \mathrm{PbX}_{3}\right.$, $\mathrm{X}=$ halogen) and its mixed-halide crystals, corresponding to the 3D perovskite structures, have been used as light harvesters for solar cells $[\underline{42}, \underline{45}, \underline{49}, \underline{52}, \underline{53}, \underline{57}, \underline{58}]$. Bandgap tuning of $\mathrm{MAPbX}_{3}$ has been achieved via the substitution of I with $\mathrm{Cl} / \mathrm{Br}$ ions, which arises from a strong dependence of electronic energies on the effective exciton mass [102]. The optical absorption can be controllably tuned by bandgap engineering to cover almost the entire visible spectrum. Meanwhile, the incorporation of $\mathrm{Cl} / \mathrm{Br}$ into an iodide-based structure dramatically improves the charge transport and the separation kinetics within the perovskite layer [103]. As a result of the tunable composition of the light harvester in conjunction with a mesoporous $\mathrm{TiO}_{2}$ film and a holeconducting polymer, $\operatorname{MAPb}\left(\mathrm{I}_{1-\mathrm{x}} \mathrm{Br}_{\mathrm{x}}\right)_{3}$ and $\mathrm{MAPb}\left(\mathrm{I}_{1-\mathrm{x}} \mathrm{Cl}_{\mathrm{x}}\right)_{3}$ were experimentally demonstrated to improve the efficiency and the relative stability of perovskite solar cells $[32,33,39,43,44,47,48,56]$. It was found that an increase in 
(a)



(b)

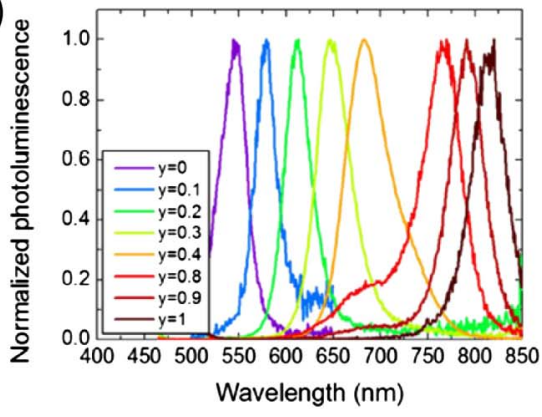

(c)

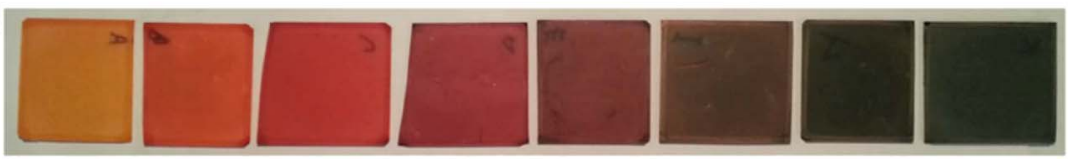

Fig. 4. (a) UV-Vis absorbance of the $\mathrm{FAPbI}_{\mathrm{y}} \mathrm{Br}_{3-\mathrm{y}}$ perovskite with varying $\mathrm{y}$, measured in an integrating sphere. (b) Corresponding steady-state photoluminescence spectra for the same films. (c) Photographs of the $\mathrm{FAPbI}_{\mathrm{y}} \mathrm{Br}_{3-\mathrm{y}}$ perovskite films with y increasing from 0 to 1 (left to right). Adapted with permission from Ref. [59].

the cation size of perovskite materials resulted in a reduction in the bandgap. A tunable bandgap between 1.48 and $2.23 \mathrm{eV}$ can be obtained (Fig. 4) by replacing the methylammonium cation in perovskite with a slightly larger formamidinium cation [59]. Importantly, the reduced bandgap led to high shortcircuit currents of $>23 \mathrm{~mA} \mathrm{~cm}^{-2}$ and PCE of up to $14.2 \%$, which is the highest efficiency yet for solution-processed p-i-n perovskite solar cells.

As far as the preparation methods of perovskite thin films are concerned, solution-based techniques have been proposed to fabricate thin films, in which a mixture of two precursors is used to form the final absorber $[30,31,34-36]$. Due to the lack of suitable solvents that can dissolve both components, and the high reaction rate of the perovskite component, this process often results in thin films with pinhole formation and incomplete surface coverage, which deteriorates the film quality and hampers the device performance.

To this end, a two-step deposition technique was created to prepare hybrid perovskite [104]. First, a layer of metal halide, $\mathrm{PbI}_{2}$, was deposited using the spin-coating method, followed by dipping the film into an organic salt solution. The two-step deposition technique is expected to be particularly useful for preparing films of organic-inorganic systems, in which the organic and inorganic components have incompatible solubility characteristics, or for systems in which the organic component is difficult to evaporate. Later on, this technique was used for the fabrication of solid-state mesoscopic solar cells, which greatly increased the reproducibility of the cell performance and allowed a PEC above 15\% [45]. It should be noted that this method has been largely successful in films with nanostructured $\mathrm{TiO}_{2}$ scaffolds, but is seldom reported to be applicable for fabricating p-i-ns. Moreover, the two-step process also often results in films with significantly large surface roughness that were frequently peeled off from the substrate $[77,104]$. Very recently, the two-step deposition technique was modified. A low-temperature vapor-assisted solution process was demonstrated to construct polycrystalline perovskite thin films with full surface coverage, small surface roughness, and grain size up to microscale. In particular, the key step is the film growth via in situ reaction of the as-deposited film of $\mathrm{PbI}_{2}$ with $\mathrm{CH}_{3} \mathrm{NH}_{3} \mathrm{I}$ vapor. It takes advantage of the kinetic reactivity of $\mathrm{CH}_{3} \mathrm{NH}_{3} \mathrm{I}$ and the thermodynamic stability of perovskite during the in situ growth process and provides films with a well-defined grain structure and grain sizes up to microscale, full surface coverage, and small surface roughness. Devices based on the planar $\mathrm{CH}_{3} \mathrm{NH}_{3} \mathrm{PbI}_{3}$ thin film via the modified two-step deposition technique achieved a best PCE of 12.1\% [57].

Apart from the techniques addressed previously, vacuum evaporation is considered as a high-performance technique to grow oriented thin films of layered perovskite with a precise control of the film properties [32]. Dual-source vapordeposited organometal trihalide perovskite solar cells based on a p-i-n thin-film architecture were developed that present a PEC over $15 \%$ with a $V_{\text {oc }}$ of $1.07 \mathrm{~V}$ (Fig. 5). However, the deposition with the vacuum evaporation method might be disadvantageous for low-cost solar cell manufacturing.

\section{Hole Conductor Materials}

The trade-off between the series and shunt resistance in perovskite solar cells was controlled somehow by the performance of perovskite and/or HTM. It is well known that perovskite is highly conductive, on the order of $10^{-3} \mathrm{~S} \mathrm{~cm}^{-3}$, which requires a thick layer of HTM to avoid pinholes. Even the widely used HTMs, for example, spiro-OMeTAD, are less conductive $\left(\sim 10^{-5} \mathrm{~S} \mathrm{~cm}^{-1}\right)$. Its thicker capping layer results in high series resistance [36]. It is indisputable that the HTMs play an important role in perovskite solar cells. These perovskite solar cells typically employ a wide variety of organic polymer hole conductors. One of the most notable holeconducting polymers is spiro-OMeTAD [24]. So far, most of the record-holding perovskite solar cells use spiro-OMeTAD as the HTMs as shown in Table 1. Furthermore, the use of protic ionic liquids (PILs) as effective p-dopants in hybrid solar cells based on triarylamine hole-transporting materials has been demonstrated. The results showed improved PCE by replacing the lithium salts, typical p-dopants for spiroOMeTAD, with PILs [47]. Photovoltage-photocurrent decay and photo-induced absorption established that the significantly improved device performance was attributed to reduced charge transport resistance in the hole-transporting matrix potentiated by PIL doping. Additionally, the dependence of spiro-OMeTAD, P3HT, and 4-(diethylamino)-benzaldehydediphenylhydrazone (DEH) as HTMs on the performance 

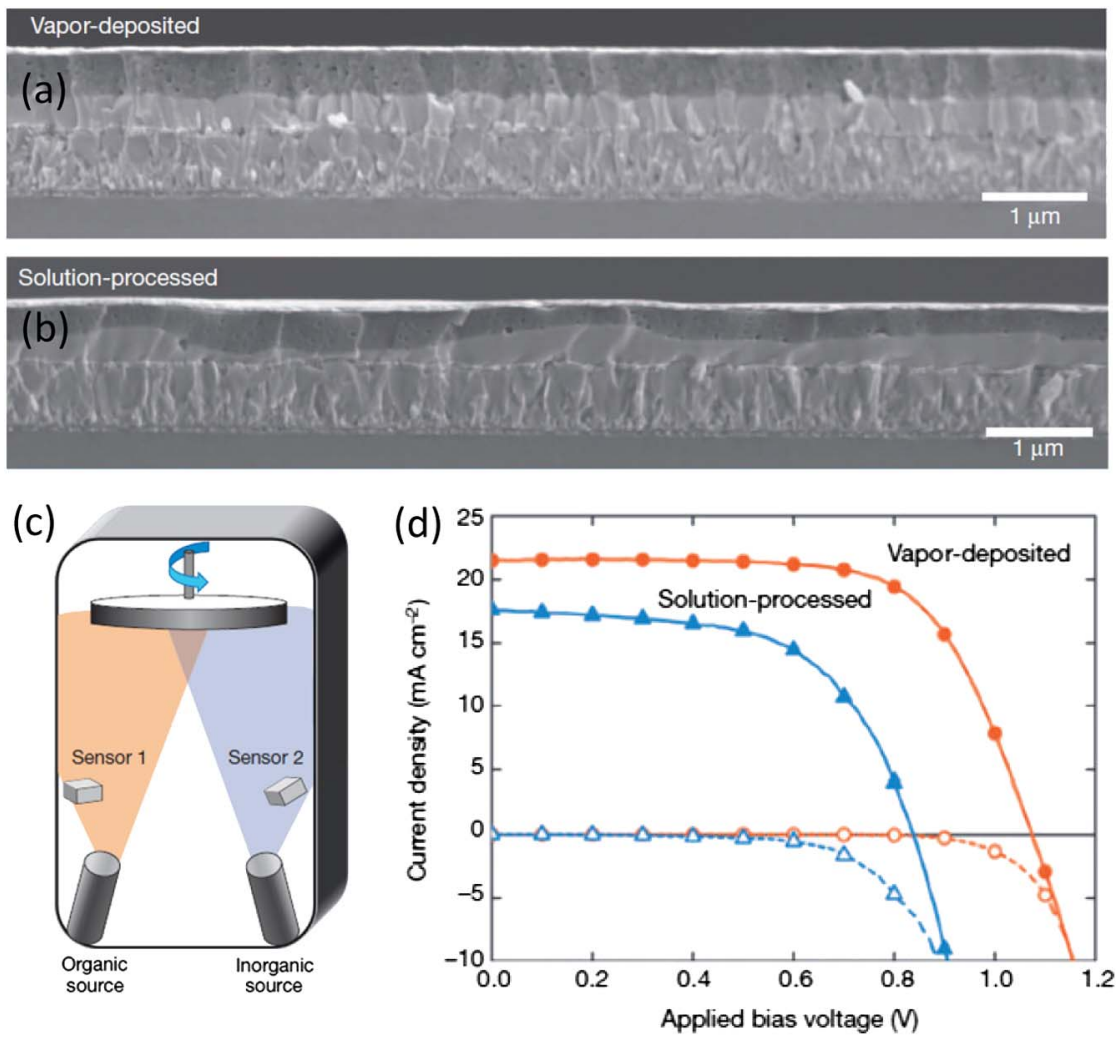

Fig. 5. Cross-sectional SEM images under lower magnification of completed solar cells constructed from (a) vapor-deposited perovskite film and (b) solution-processed perovskite film. (c) Schematic of dual-source thermal evaporation system for depositing the perovskite absorbers; the organic source was methylammonium iodide, and the inorganic source was $\mathrm{PbCl}_{2}$. (d) Current-density/voltage curves of the best-performing solution-processed (blue lines, triangles) and vapor-deposited (red lines, circles) p-i-n perovskite solar cells measured under simulated AM1.5 sunlight of $101 \mathrm{~mW} \mathrm{~cm}^{-2}$ irradiance (solid lines) and in the dark (dashed lines). Adapted with permission from Ref. [32].

of perovskite solar cells was studied [눙. The results suggested that the recombination of the separated charges in the device using spiro-OMeTAD HTM was more than 10 times slower compared to that in the device with P3HT, and more than 100 times slower than that in the device with DEH HTM. Recently, a set of three N,N-di-p-methoxyphenylamine-substituted pyrene derivatives has been successfully synthesized and characterized. The pyrene-based derivative Py-C exhibited an overall PCE of 12.7\% [53]. The performance is comparable to that of the well-studied spiro-OMeTAD, even though the $V_{\text {oc }}$ is slightly lower. On the other hand, PEDOT:PSS was also employed as an HTM (substrate/ITO/PEDOT: PSS/ $\mathrm{CH}_{3} \mathrm{NH}_{3} \mathrm{PbI}_{3-\mathrm{x}} \mathrm{Cl}_{\mathrm{x}} / \mathrm{PCBM} / \mathrm{Al}$, where PEDOT:PSS and PCBM are used as hole and electron transport layers, respectively).
Such architecture allowed the fabrication of a flexible perovskite solar cell with a PCE of $9.2 \%$ by replacing the rigid glass/ ITO substrate with a flexible PET/ITO substrate (Fig. 6) [60].

However, the widely used organic hole conductors including spiro-OMeTAD and $\mathrm{P} 3 \mathrm{HT}$ may represent a potential hurdle to the future commercialization of this type of solar cell because of their relatively high cost. To this end, a $\mathrm{CH}_{3} \mathrm{NH}_{3} \mathrm{PbI}_{3}$ perovskite-sensitized solar cell utilizing an inexpensive, stable, solution-processable inorganic $\mathrm{CuI}$ as the hole conductor has been demonstrated [52]. It was also demonstrated that the solution-processable p-type direct bandgap semiconductor $\mathrm{CsSnI}_{3}$ with perovskite structure can also be used for hole conduction replacing a liquid electrolyte [41]. The resulting solid-state DSSCs consist of $\mathrm{CsSnI}_{2.95} \mathrm{~F}_{0.05}$ dope


Fig. 6. (a) Photo image of flexible perovskite solar cells on the PET/ITO substrate and (b) device performance of the perovskite solar cells on the PET/ITO flexible substrate before and after bending. Adapted with permission from Ref. [60]. 
casted with $\mathrm{SnF}_{2}$, nanoporous $\mathrm{TiO}_{2}$, and the N719 dye, and show conversion efficiencies of up to $10.2 \%$.

It is worth noting that the perovskite materials simultaneously play the roles of light harvesters and hole conductors, rendering superfluous the use of an additional HTM. Recently, a hole-conductor-free mesoscopic $\mathrm{CH}_{3} \mathrm{NH}_{3} \mathrm{PbI}_{3}$ perovskite/ $\mathrm{TiO}_{2}$ heterojunction solar cell was reported, which showed the photovoltaic performance with $J_{\mathrm{sc}}=16.1 \mathrm{~mA} / \mathrm{cm}^{2}$, $V_{\mathrm{oc}}=0.631 \mathrm{~V}$, and a $\mathrm{FF}=0.57$, corresponding to a PCE of $5.5 \%$ [36]. However, the photovoltaic performance is still inferior to that with the HTM.

\section{E. Charge-Carrier Mobility, Lifetime, and Diffusion Lengths in Perovskite Materials}

Despite the rapid improvement in efficiency associated with the evolution of solution/vapor-processed perovskite solar cells, most of the fundamental questions concerning the photo physics remain unanswered. One of the most critical questions is what the exciton or the electron and hole diffusion lengths are in these materials. Concrete evidence of balanced long-range electron-hole diffusion lengths of at least $100 \mathrm{~nm}$ in solution-processed $\mathrm{CH}_{3} \mathrm{NH}_{3} \mathrm{PbI}_{3}$ was obtained by applying femtosecond transient optical spectroscopy to bilayers that interface this perovskite with either selective-electron or selective-hole extraction materials [61]. It is demonstrated that the high photo conversion efficiencies of these systems stem from the comparable optical absorption length and charge-carrier diffusion lengths, transcending the traditional constraints of solution-processed semiconductors. In the meantime, photoluminescence quenching measurements were performed in order to extract the electron-hole diffusion lengths in triiodide $\left(\mathrm{CH}_{3} \mathrm{NH}_{3} \mathrm{PbI}_{3}\right)$ and mixed-halide $\left(\mathrm{CH}_{3} \mathrm{NH}_{3} \mathrm{PbI}_{3-\mathrm{x}} \mathrm{Cl}_{\mathrm{x}}\right)$ perovskite thin films (Fig. 7) [르]. It is found that both electron and hole diffusion lengths are $>1 \mu \mathrm{m}$ for the mixed-halide perovskite-a factor of $\sim 5$ to 10 greater than the absorption depth. In comparison, the diffusion lengths in the triiodide perovskite are only on the order of or slightly shorter than the absorption depth $(\sim 100 \mathrm{~nm})$. The larger diffusion length in the mixed-halide perovskite results from a much longer recombination lifetime and is consistent with the far superior performance in MSSCs and p-i-n solar cells. However, the mechanism causing such an extended diffusion length remains unclear. Long charge-carrier diffusion distances require both low recombination rates and/or high charge mobility. Satisfying both requirements simultaneously is generally difficult given the fundamental Langevin limit for kinetic recombination, which typically holds for conductors with charge mobilities below the order of $1-10 \mathrm{~cm}^{2} \mathrm{~V}^{-1} \mathrm{~s}^{-1}$ [105]. By using transient terahertz spectroscopy, it has been found that bimolecular recombination rates are abnormally low in perovskite materials, defying the Langevin limit by at least four orders of magnitude. Meanwhile, lower bounds were also established for the high-frequency charge mobilities of $11.6 \mathrm{~cm}^{2} \mathrm{~V}^{-1} \mathrm{~s}^{-1}$ for $\mathrm{CH}_{3} \mathrm{NH}_{3} \mathrm{PbI}_{3-\mathrm{x}} \mathrm{Cl}_{\mathrm{x}}$ and $8 \mathrm{~cm}^{2} \mathrm{~V}^{-1} \mathrm{~s}^{-1}$ for $\mathrm{CH}_{3} \mathrm{NH}_{3} \mathrm{PbI}_{3}$, which were remarkably high for solution-processed materials [63]. The combination of high charge mobility and low bimolecular recombination leads to carrier diffusion lengths that exceed $1 \mu \mathrm{m}$ and are significantly longer for the mixed-halide system. Still, there remain many open questions for the community concerning the nature of the excited state, the relative fraction of free and bound charge pairs at room temperature, and the interplay between the two species [62].

\section{CONCLUSIONS AND FUTURE OUTLOOK}

In summary, organic-inorganic hybrid halide perovskite solar cells exhibit impressive competitiveness with other photovoltaic techniques due to their unique advantages: (i) low-cost, earth abundance, and easy preparation; (ii) near-perfect crystallinity at low temperature; (iii) large charge-carrier diffusion length of approximately $1 \mu \mathrm{m}$ for mixed-halide perovskite $\left(\mathrm{CH}_{3} \mathrm{NH}_{3} \mathrm{PbI}_{3-\mathrm{x}} \mathrm{Cl}_{\mathrm{x}}\right)$ thin films, which is 100 times higher that the other low-temperature solution-processed thin films [62]; and (iv) lower value of "loss-in-potential" in a solar cell, which allows the $V_{\text {oc }}$ of the best perovskite cells to be greater than $1.1 \mathrm{~V}$ [106]. The value is much higher than the traditional DSSCs, organic solar cells (0.7-0.8 eV), and CdTe (0.59 eV). It can even compete with crystal silicon solar cells $(1.1 \mathrm{eV})$. (v) Its bandgap can be tuned in the range of 1.48$2.23 \mathrm{eV}$ by replacing the methylammonium cation with the slightly larger formamidinium cation [59] and/or part substitution of I with $\mathrm{Br} / \mathrm{Cl}$ ions $[39,43,44,47,48]$. (vi) Perovskite materials are better than silicon at absorbing higher-energy blue and green photons [하] .

Meanwhile, perovskite materials also have some ineluctable disadvantages: (i) perovskite materials are extremely sensitive to oxygen and water vapor, which reacts to break down the crystal structure and dissolves the saltlike perovskite, respectively. The preparation of perovskite thin films should be performed in inert atmosphere. (ii) It is challenging
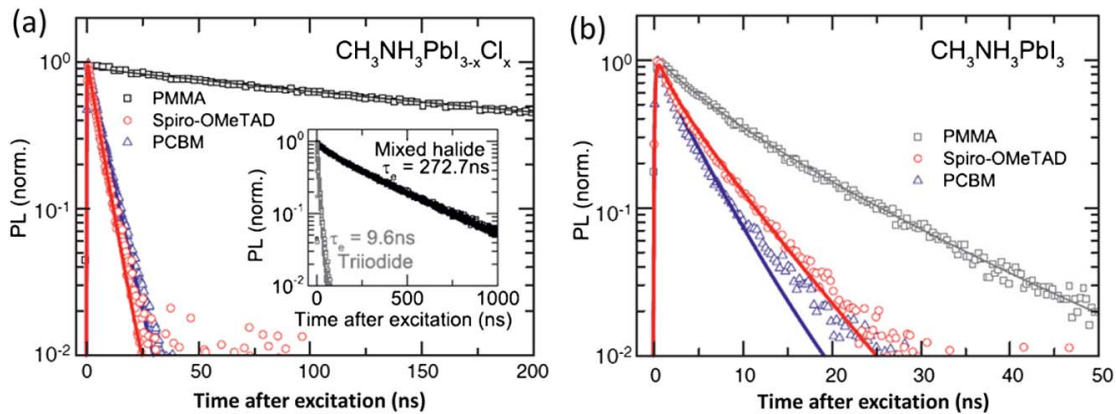

Fig. 7. Time-resolved PL measurements taken at the peak emission wavelength of (a) mixed-halide perovskite and (b) triiodide perovskite with an electron (PCBM, blue triangles) or hole (spiro-OMeTAD, red circles) quencher layer, along with stretched exponential fits to the PMMA data (black squares) and fits to the quenching samples by using the diffusion model described in the text. A pulsed ( 0.3 to $10 \mathrm{MHz})$ excitation source at $507 \mathrm{~nm}$ with a fluence of $30 \mathrm{~nJ} / \mathrm{cm}^{2}$ impinged on the glass substrate side. (Inset) Comparison of the PL decay of the two perovskites (with PMMA) on a longer time scale, with lifetimes $\tau_{\mathrm{e}}$ quoted as the time taken to reach 1/e of the initial intensity. Adapted with permission from Ref. [62]. 
to prepare large continuous films, which limits it for largescale production. (iii) The lead in the most-used perovskite solar cells is toxic and could leach out of the solar panel onto rooftops or the soil below. (iv) Since there is a phase transition from tetragonal to cubic at $55^{\circ} \mathrm{C}$, the longer-term stability of perovskite solar cells has not been verified. There are a few studies on storage lifetime but only limited on an operating cell (under illumination at the maximum power) for a sealed cell at $45^{\circ} \mathrm{C}[45]$. The study showed a decrease in efficiency of less than $20 \%$ after $500 \mathrm{~h}$.

In view of the advantages and disadvantages addressed above, some new strategies can be forwarded to further improve the efficiency of perovskite solar cells: (i) the broad family and the tunable bandgap of perovskite materials, in addition to quantum confinement in layered perovskite, allow absorption toward $940 \mathrm{~nm}$, which would significantly enhance the efficiency; (ii) employing higher-mobility and lower-cost hole transporters would improve the $\mathrm{FF}$ and decrease the cost. Additionally, improving the quality of the contact layers by advanced deposition techniques (e.g., spray deposition, thermal evaporation) among the photoanode, perovskite, and hole transporters may also lead to enhanced FF. (iii) Considering that the current system employing perovskite matches well with crystalline silicon and other thin-film technologies such as CIGS and CZTSSe, a tandem solar cell combining the perovskite solar cell with a crystalline silicon cell/CIGS/CZTSSe would further improve the efficiency. An efficiency up to $29.6 \%$ is predicated [67].

Needless to say, the development of higher-efficiency solar cells will not only have a profound economic impact, but it will also represent significant social and environmental benefits. The perovskite technology would allow the mass production of solar cells with high efficiency and at relatively low temperatures, which would account for a substantial reduction of cost. In the meantime, the technology can lead to high-throughput device fabrication due to the simple deposition process required. Furthermore, flexible substrates could be used, which would allow an easier handling, transportation, installation, and building integration of these new photovoltaic devices. We believe that this new class of MSSCs and/or p-i-n perovskite solar cells will find widespread applications and will eventually lead to devices that rival conventional silicon-based photovoltaics.

\section{ACKNOWLEDGMENTS}

The authors acknowledge support from the Victorian Government under the Victoria Science Agenda (VSA) scheme. Min $\mathrm{Gu}$ and Baohua Jia thank the Australian Research Council for its support (DP140100849). Min Gu also acknowledges support from the Science and Industry Endowment Fund.

\section{REFERENCES}

1. S. B. Darling, F. Q. You, T. Veselka, and A. Velosa, "Assumptions and the levelized cost of energy for photovoltaics," Energy Environ. Sci. 4, 3133-3139 (2011).

2. D. J. Yue, P. Khatav, F. Q. You, and S. B. Darling, "Deciphering the uncertainties in life cycle energy and environmental analysis of organic photovoltaics," Energy Environ. Sci. 5, 9163-9172 (2012).

3. IEA-ETSAP and IRENA Technology Brief E11 (2013).

4. K. Efthymios and R. Bryce, "Improvement in multi-crystalline silicon solar cell efficiency via addition of luminescent material to EVA encapsulation layer,” Prog. Photovoltaics Res. Appl. 19, 345-351 (2011).

5. D. Ginley, M. A. Green, and R. Collins, "Solar energy conversion toward 1 terawatt," MRS Bull. 33, 355-364 (2008).

6. P. Jackson, D. Hariskos, E. Lotter, S. Paetel, and R. Wuerz, "New world record efficiency for $\mathrm{Cu}(\mathrm{In}, \mathrm{Ga}) \mathrm{Se}_{2}$ thin-film solar cells beyond 20\%," Prog. Photovoltaics Res. Appl. 19, 894-897 (2011).

7. X. Chen, B. H. Jia, Y. N. Zhang, and M. Gu, "Exceeding the limit of plasmonic light trapping in textured screen-printed solar cells using Al nanoparticles and wrinkle-like graphene sheets," Light Sci. Appl. 2, e92 (2013).

8. C. J. Hibberd, E. Chassaing, W. Liu, D. B. Mitzi, and D. Lincot, "Non-vacuum methods for formation of $\mathrm{Cu}(\mathrm{In}, \mathrm{Ga})(\mathrm{Se}, \mathrm{S})_{2}$ thin film photovoltaic absorbers," Prog. Photovoltaics Res. Appl. 18, 434-452 (2010).

9. W. M. Robert, Z. Guillaume, and F. Ian, "Inorganic photovoltaic cells," Mater. Today 10(11), 20-27 (2007).

10. B. O'Regan and M. Grätzel, "A low-cost, high-efficiency solar cell based on dye-sensitized colloidal $\mathrm{TiO}_{2}$ films," Nature $\mathbf{3 5 3}$, 737-740 (1991)

11. A. Hagfeldt, G. Boschloo, L. C. Sun, L. Kloo, and H. Pettersson, "Dye-sensitized solar cells," Chem. Rev. 110, 6595-6663 (2010).

12. J. Y. Cong, X. C. Yang, L. Kloo, and L. C. Sun, "Iodine/iodide-free redox shuttles for liquid electrolyte-based dye-sensitized solar cells," Energy Environ. Sci. 5, 9180-9194 (2012).

13. N. Tetreault and M. Grätzel, "Novel nanostructures for next generation dye-sensitized solar cells," Energy Environ. Sci. 5, 8506-8516 (2012).

14. G. Boschloo and A. Hagfeldt, "Characteristics of the iodide/ triiodideredox mediator in dye-sensitized solar cells," Acc. Chem. Res. 42, 1819-1826 (2009).

15. J. H. Yum, E. Baranoff, F. Kessler, T. Moehl, and S. Ahmad, "A cobalt complex redox shuttle for dye-sensitized solar cells with high open-circuit potentials," Nat. Commun. 3, 631 (2012).

16. E. Mosconi, J. H. Yum, F. Kessler, C. J. Gomez-Garcia, and C. Zuccaccia, "Cobalt electrolyte/dye interactions in dye-sensitized solar cells: a combined computational and experimental study," J. Am. Chem. Soc. 134, 19438-19453 (2012).

17. S. M. Feldt, E. A. Gibson, E. Gabrielsson, L. C. Sun, and G. Boschloo, "Design of organic dyes and cobalt polypyridineredox mediators for high-efficiency dye-sensitized solar cells,” J. Am. Chem. Soc. 132, 16714-16724 (2010).

18. C. K. Xu, J. M. Wu, U. V. Desai, and D. Gao, "Multilayer assembly of nanowire arrays for dye-sensitized solar cells," J. Am. Chem. Soc. 133, 8122-8125 (2011).

19. M. Law, L. E. Greene, J. C. Johnson, R. Saykally, and P. Yang, "Nanowire dye-sensitized solar cells," Nat. Mater. 4, 455-459 (2005).

20. B. Liu and E. S. Aydil, "Growth of oriented single-crystalline rutile $\mathrm{TiO}_{2}$ nanorods on transparent conducting substrates for dye-sensitized solar cells," J. Am. Chem. Soc. 131, 3985-3990 (2009).

21. D. B. Kuang, J. Brillet, P. Chen, M. Takata, and S. Uchida, "Application of highly ordered $\mathrm{TiO}_{2}$ nanotube arrays in flexible dye-sensitized solar cells," ACS Nano 2, 1113-1116 (2008).

22. Q. L. Huang, G. Zhou, L. Fang, L. P. Hua, and Z. S. Wang, "TiO nanorod arrays grown from a mixed acid medium for efficient dye-sensitized solar cells," Energy Environ. Sci. 4, 2145-2151 (2011).

23. A. Yella, H. W. Lee, H. N. Tsao, C. Y. Yi, and A. K. Chandiran, "Porphyrin-sensitized solar cells with cobalt (II/III)-based redox electrolyte exceed 12 percent efficiency," Science 334, 629-634 (2011).

24. U. Bach, D. Lupo, P. Comte, J. E. Moser, and F. Weissortel, "Solid-state dye-sensitized mesoporous $\mathrm{TiO}_{2}$ solar cells with high photon-to-electron conversion efficiencies," Nature $\mathbf{3 9 5}$ 583-585 (1998).

25. L. Yang, U. B. Cappel, E. L. Unger, M. Karlsson, and K. M. Karlsson, "Comparing spiro-OMeTAD and P3HT hole conductors in efficient solid state dye-sensitized solar cells," Phys. Chem. Chem. Phys. 14, 779-789 (2012).

26. W. Zhang, R. Zhu, F. Li, Q. Wang, and B. Liu, "High-performance solid-state organic dye sensitized solar cells with P3HT as hole transporter,” J. Phys. Chem. C 115, 7038-7043 (2011). 
27. S. X. Tan, J. Zhai, M. X. Wan, Q. B. Meng, and Y. L. Li, "Influence of small molecules in conducting polyaniline on the photovoltaic properties of solid-state dye-sensitized solar cells," J. Phys. Chem. B 108, 18693-18697 (2004).

28. K. Murakoshi, R. Kogure, Y. Wada, and S. Yanagida, "Fabrication of solid-state dye-sensitized $\mathrm{TiO}_{2}$ solar cells combined with polypyrrole," Sol. Energy Mater. Sol. Cells 55, 113-125 (1998).

29. J. Krüger, R. Plass, L. Cevey, M. Piccirelli, and M. Grätzel, "High efficiency solid-state photovoltaic device due to inhibition of interface charge recombination," Appl. Phys. Lett. 79, 2085-2087 (2001).

30. A. Kojima, K. Teshima, Y. Shirai, and T. Miyasaka, "Organometal halide perovskites as visible-light sensitizers for photovoltaic cells,” J. Am. Chem. Soc. 131, 6050-6051 (2009).

31. H. S. Kim, C. R. Lee, J. H. Im, K. B. Lee, and T. Moehl, "Lead iodide perovskite sensitized all-solid-state submicron thin film mesoscopic solar cell with efficiency exceeding $9 \%$, Sci. Rep. 2, 591 (2012)

32. M. Liu, M. B. Johnston, and H. J. Snaith, "Efficient planar heterojunction perovskite solar cells by vapour deposition," Nature 501, 395-398 (2013).

33. K. Wojciechowski, M. Saliba, T. Leijtens, A. Abate, and H. J. Snaith, "Sub- $150^{\circ} \mathrm{C}$ processed meso-superstructured perovskite solar cells with enhanced efficiency," Energy Environ. Sci. 7, 1142-1147 (2014).

34. J. H. Im, C. R. Lee, J. W. Lee, S. W. Park, and N. G. Park, "6.5\% efficient perovskite quantum-dot-sensitized solar cell," Nanoscale 3, 4088-4093 (2011).

35. M. M. Lee, J. Teuscher, T. Miyasaka, T. N. Murakami, and H. J. Snaith, "Efficient hybrid solar cells based on mesosuperstructured organometal halide perovskites," Science 338, 643-647 (2012).

36. L. Etgar, P. Gao, Z. S. Xue, Q. Peng, and A. K. Chandiran, "Mesoscopic $\mathrm{CH}_{3} \mathrm{NH}_{3} \mathrm{PbI}_{3} / \mathrm{TiO}_{2}$ heterojunction solar cells," J. Am. Chem. Soc. 134, 17396-17399 (2012).

37. S. S. Shin, J. S. Kim, J. H. Suk, K. D. Lee, and D. W. Kim, "Improved quantum efficiency of highly efficient perovskite $\mathrm{BaSnO}_{3}$-based dye-sensitized solar cells," ACS Nano 7, 1027-1035 (2013)

38. E. Edri, S. Kirmayer, D. Cahen, and G. Hodes, "High open-circuit voltage solar cells based on organic-inorganic lead bromide perovskite," J. Phys. Chem. Lett. 4, 897-902 (2013).

39. J. H. Noh, S. H. Im, J. H. Heo, T. N. Mandal, and S. I. Seok, "Chemical management for colorful, efficient, and stable inorganic-organic hybrid nanostructured solar cells," Nano Lett. 13, 1764-1769 (2013).

40. D. Q. Bi, L. Yang, G. Boschloo, A. Hagfeldt, and E. M. J. Johansson, "Effect of different hole transport materials on recombination in $\mathrm{CH}_{3} \mathrm{NH}_{3} \mathrm{PbI}_{3}$ perovskite-sensitized mesoscopic solar cells," J. Phys. Chem. Lett. 4, 1532-1536 (2013).

41. I. Chung, B. H. Lee, J. Q. He, R. P. H. Chang, and M. G. Kanatzidis, "All-solid-state dye-sensitized solar cells with high efficiency," Nature 485, 486-489 (2012).

42. H. S. Kim, J. W. Lee, N. Yantara, P. P. Boix, and S. A. Kulkarni, "High efficiency solid-state sensitized solar cell-based on submicrometer rutile $\mathrm{TiO}_{2}$ nanorod and $\mathrm{CH}_{3} \mathrm{NH}_{3} \mathrm{PbI}_{3}$ perovskite sensitizer," Nano Lett. 13, 2412-2417 (2013).

43. A. Abrusci, S. D. Stranks, P. Docampo, H. L. Yip, and A. K. Y. Jen, "High performance perovskite-polymer hybrid solar cells via electronic coupling with fullerene monolayers," Nano Lett. 13, 3124-3128 (2013).

44. J. M. Ball, M. M. Lee, A. Hey, and H. J. Snaith, "Low-temperature processed meso-superstructured to thin-film perovskite solar cells," Energy Environ. Sci. 6, 1739-1743 (2013).

45. J. Burschka, N. Pellet, S. J. Moon, R. Humphry-Baker, and P. Gao, "Sequential deposition as a route to high-performance perovskite-sensitized solar cells," Nature 499, 316-319 (2013).

46. W. Zhang, M. Saliba, S. D. Stranks, Y. Sun, and X. Shi, "Enhancement of perovskite-based solar cells employing core-shell metal nanoparticles," Nano Lett. 13, 4505-4510 (2013).

47. A. Abate, D. J. Hollman, J. Teuscher, S. Pathak, and R. Avolio, "Protic ionic liquids as p-dopant for organic hole transporting materials and their application in high efficiency hybrid solar cells," J. Am. Chem. Soc. 135, 13538-13548 (2013).
48. G. E. Eperon, V. M. Burlakov, P. Docampo, A. Goriely, and H. J Snaith, "Morphological control for high performance, solutionprocessed planar heterojunction perovskite solar cells," Adv. Funct. Mater. 24, 151-157 (2014).

49. D. Q. Bi, S. J. Moon, L. Häggman, G. Boschloo, and L. Yang, "Using a two-step deposition technique to prepare perovskite $\left(\mathrm{CH}_{3} \mathrm{NH}_{3} \mathrm{PbI}_{3}\right)$ for thin film solar cells based on $\mathrm{ZrO}_{2}$ and $\mathrm{TiO}_{2}$ mesostructures," RSC Adv. 3, 18762-18766 (2013).

50. J. H. Qiu, Y. C. Qiu, K. Y. Yan, M. Zhong, and C. Mu, "All-solidstate hybrid solar cells based on a new organometal halide perovskite sensitizer and one-dimensional $\mathrm{TiO}_{2}$ nanowire arrays," Nanoscale 5, 3245-3248 (2013).

51. D. Q. Bi, G. Boschloo, S. Schwarzmüller, L. Yang, and E. M. J. Johansson, "Efficient and stable $\mathrm{CH}_{3} \mathrm{NH}_{3} \mathrm{PbI}_{3}$-sensitized $\mathrm{ZnO}$ nanorod array solid-state solar cells," Nanoscale 5, 11686-11691 (2013).

52. J. A. Christians, R. C. M. Fung, and P. V. Kamat, "An inorganic hole conductor for organo-lead halide perovskite solar cells Improved hole conductivity with copper iodide," J. Am. Chem. Soc. 136, 758-764 (2014).

53. N. JoongJeon, J. Lee, J. H. Noh, M. K. Nazeeruddin, and M. Grätzel, "Efficient inorganic-organic hybrid perovskite solar cells based on pyrenearylamine derivatives as hole-transporting materials," J. Am. Chem. Soc. 135, 19087-19090 (2013).

54. T. M. Koh, K. W. Fu, Y. N. Fang, S. Chen, and T. C. Sum, "Formamidinium-containing metal-halide: an alternative material for near-IR absorption perovskite solar cells," J. Phys. Chem. C 118, 16458-16462 (2014).

55. B. Conings, L. Baeten, C. D. Dobbelaere, J. D'Haen, and J. Manca, "Perovskite-based hybrid solar cells exceeding $10 \%$ efficiency with high reproducibility using a thin film sandwich approach," Adv. Mater. 26, 2041-2046 (2014).

56. J. T. W. Wang, J. M. Ball, E. M. Barea, A. Abate, and J. A. Alexander-Webber, "Low-temperature processed electron collection layers of Graphene/ $\mathrm{TiO}_{2}$ nanocomposites in thin film perovskite solar cells," Nano Lett. 14, 724-730 (2014).

57. Q. Chen, H. P. Zhou, Z. R. Hong, S. Luo, and H. S. Duan, "Planar heterojunction perovskite solar cells via vapor-assisted solution process," J. Am. Chem. Soc. 136, 622-625 (2014).

58. D. Y. Liu and L. Kelly, "Perovskite solar cells with a planar heterojunction structure prepared using room-temperature solution processing techniques," Nat. Photonics 8, 133-138 (2014).

59. G. E. Eperon, S. D. Stranks, C. Menelaou, M. B. Johnston, and L. M. Herz, "Formamidinium lead trihalide: a broadly tunable perovskite for efficient planar heterojunction solar cells," Energy Environ. Sci. 7, 982-988 (2014).

60. J. B. You, Z. R. Hong, Y. Yang, Q. Chen, and M. Cai, "Lowtemperature solution-processed perovskite solar cells with high efficiency and flexibility," ACS Nano 8, 1674-1680 (2014).

61. G. H. Xing, N. Mathews, S. Y. Sun, S. S. Lim, and Y. M. Lam, "Long-range balanced electron- and hole-transport lengths in organic-inorganic $\mathrm{CH}_{3} \mathrm{NH}_{3} \mathrm{PbI}_{3}$," Science 342, 344-347 (2013).

62. S. D. Stranks, G. E. Eperon, G. Grancini, C. Menelaou, and M. J. P. Alcocer, "Electron-hole diffusion lengths exceeding 1 micrometer in an organometal trihalide perovskite absorber," Science 342, 341-344 (2013).

63. C. Wehrenfennig, G. E. Eperon, M. B. Johnston, H. J. Snaith, and L. M. Herz, "High charge carrier mobilities and lifetimes in organolead trihalide perovskites," Adv. Mater. 26, 1584-1589 (2014).

64. G. Hodes, "Perovskite-based solar cells," Science 342, 317-318 (2013).

65. R. F. Service, "Turning up the light," Science 342, 794-797 (2013).

66. M. He, D. G. Zheng, M. Y. Wang, C. J. Lin, and Z. Q. Lin, "High efficiency perovskite solar cells: from complex nanostructure to planar heterojunction,” J. Mater. Chem. 2, 5994-6003 (2014).

67. H. J. Snaith, "Perovskites: the emergence of a new era for low-cost, high-efficiency solar cells,” J. Phys. Chem. Lett. 4, 3623-3630 (2013).

68. J. H. Rhee, C. C. Chung, and E. W. G. Diau, "A perspective of mesoscopic solar cells based on metal chalcogenide quantum dots and organometal-halide perovskites," NPG Asia Mater. 5, e68 (2013). 
69. N. G. Park, "Organometal perovskite light absorbers toward a $20 \%$ efficiency low-cost solid-state mesoscopic solar cell," J. Phys. Chem. Lett. 4, 2423-2429 (2013)

70. I. Borriello, G. Cantele, and D. Ninno, "Ab initio investigation of hybrid organic-inorganic perovskites based on tin halides," Phys. Rev. B 77, 235214 (2008).

71. G. Shirane, H. Danner, and R. Pepinshi, "Neutron diffraction study of orthorhombic $\mathrm{BaTiO}_{3}$," Phys. Rev. 105, 856-860 (1957).

72. E. P. Giannelis, "Polymer layered silicate nanocomposites," Adv. Mater. 8, 29-35 (1996)

73. S. S. Ray and M. Okamoto, "Polymer/layered silicate nanocomposites: a review from preparation to processing," Prog. Polym. Sci. 28, 1539-1641 (2003).

74. S. S. Ray and M. Bousmina, "Biodegradable polymers and their layered silicate nanocomposites: in greening the 21st century materials world," Prog. Mater. Sci. 50, 962-1079 (2005).

75. D. B. Mitzi, "Synthesis and crystal structure of the alkylbismuth diiodides: a family of extended one-dimensional organometallic compounds," Inorg. Chem. 35, 7614-7619 (1996).

76. D. B. Mitzi, C. A. Field, Z. Schlesinger, and R. B. Laibowitz, "Transport, optical, and magnetic properties of the conducting halide perovskite $\mathrm{CH}_{3} \mathrm{NH}_{3} \mathrm{SnI}_{3}$," J. Solid State Chem. 114, 159-163 (1995).

77. O. Knop, R. E. Wasylishen, M. A. White, T. S. Cameron, and M. J. M. V. Oort, "Alkylammonium lead halides. Part 2. $\mathrm{CH}_{3} \mathrm{NH}_{3} \mathrm{PbX}_{3}$ $(\mathrm{X}=\mathrm{Cl}, \mathrm{Br}, \mathrm{I})$ perovskites: cuboctahedral halide cages with isotropic cation reorientation," Can. J. Chem. 68, 412-422 (1990).

78. C. C. Stoumpos, C. D. Malliakas, and M. G. Kanatzidis, "Semiconducting tin and lead iodide perovskites with organic cations: phase transitions, high mobilities, and near-infrared photoluminescent properties," Inorg. Chem. 52, 9019-9038 (2013).

79. A. Poglitsch and D. Weber, "Dynamic disorder in methyl ammonium trihalogenoplumbates (II) observed by millimeter-wave spectroscopy,” J. Chem. Phys. 87, 6373-6378 (1987).

80. K. Shum, Z. Chen, J. Qureshi, C. L. Yu, and J. J. Wang, "Synthesis and characterization of $\mathrm{CsSnI}_{3}$ thin films," Appl. Phys. Lett. 96 221903 (2010).

81. K. Yamada, Y. Kuranaga, K. Ueda, S. Goto, and T. Okuda, "Phase transition and electric conductivity of $\mathrm{ASnCl}_{3}$ (A = Cs and $\mathrm{CH}_{3} \mathrm{NH}_{3}$ ), Bull. Chem. Soc. Jpn. 71, 127-134 (1998).

82. Q. Xu, T. Educhi, H. Nakayama, N. Nakamura, and M. Kishita, "Molecular motions and phase transitions in solid $\mathrm{CH}_{3} \mathrm{NH}_{3} \mathrm{PbX}_{3}$ (X = Cl, Br, I) as studied by NMR and NQR," Z. Naturforsch. 46, 240-246 (1991).

83. D. B. Mitzi, S. Wang, C. A. Feild, C. A. Chess, and A. M. Guloy, "Conducting layered organic-inorganic halides containing $\langle 110\rangle$-oriented perovskite sheets," Science 267, 1473-1476 (1995).

84. D. B. Mitzi, C. A. Feild, W. T. A. Harrison, and A. M. Guloy, "Conducting tin halides with a layered organic-based perovskite structure," Nature 369, 467-469 (1994).

85. F. Chiarella, A. Zappettini, P. Ferro, T. Besagni, and F. Licci, "Growth and characterization of hybrid $\left(\mathrm{C}_{\mathrm{n}} \mathrm{H}_{2 \mathrm{n}+1} \mathrm{NH}_{3}\right)_{2} \mathrm{CuCl}_{4}$ self-assembled films," Cryst. Res. Technol. 40, 1028-1032 (2005).

86. D. B. Mitzi, "Thin-film deposition of organic-inorganic hybrid materials," Chem. Mater. 13, 3283-3298 (2001).

87. R. Valiente and F. Rodriguez, "Electron-phonon coupling in charge-transfer and crystal-field states of Jahn-Teller $\mathrm{CuCl}_{6}{ }^{4}$ systems,” Phys. Rev. B 60, 9423-9429 (1999).

88. C. R. Kagan, D. B. Mitzi, and C. D. Dimitrakopoulos, "Organicinorganic hybrid materials as semiconducting channels in thinfilm field-effect transistors," Science 286, 945-947 (1999).

89. P. Zhou, J. E. Drumheller, B. Patyal, and R. D. Willet, "Magnetic properties and critical behavior of quasi-two-dimensional systems $\left[\mathrm{C}_{6} \mathrm{H}_{5}\left(\mathrm{CH}_{2}\right)_{\mathrm{n}} \mathrm{NH}_{3}\right]_{2} \mathrm{CuBr}_{4}$ with $\mathrm{n}=1,2$, and 3," Phys. Rev. B 45, 12365-12376 (1992)

90. M. Era, S. Morimoto, T. Tsutsui, and S. Saito, "Organic-inorganic heterostructure electroluminescent device using a layered perovskite semiconductor $\left(\mathrm{C}_{6} \mathrm{H}_{5} \mathrm{C}_{2} \mathrm{H}_{4} \mathrm{NH}_{3}\right)_{2} \mathrm{PbI}_{4}$," Appl. Phys. Lett 65, 676-678 (1994).

91. X. Hong, T. Ishihara, and A. V. Nurmikko, "Dielectric confinement effect on excitons in $\mathrm{PbI}_{4}$-based layered semiconductors," Phys. Rev. B 45, 6961-6964 (1992).

92. H. J. Snaith, R. Humphry-Baker, P. Chen, I. Cesar, and S. M Zakeeruddin, "Charge collection and pore filling in solid-state dye-sensitized solar cells," Nanotechnology 19, 424003 (2008).

93. J. D. Fan, A. Shavel, R. Zamani, C. Fábrega, and J. Rousset, "Control of the doping concentration, morphology and optoelectronic properties of vertically aligned chlorine-doped $\mathrm{ZnO}$ nanowires," Acta Mater. 59, 6790-6800 (2011).

94. J. D. Fan, Y. Hao, M. G. Hernández, C. Munuera, and F. Güell, "Influence of the annealing atmosphere on the performance of ZnO nanowires-based dye-sensitized solar cells,” J. Phys. Chem. C 117, 16349-16356 (2013)

95. J. D. Fan, Y. Hao, A. Cabot, E. M. J. Johansson, and G. Boschlo, "Cobalt (II/III) redox electrolyte in $\mathrm{ZnO}$ nanowire-based dyesensitized solar cells," ACS Appl. Mater. Interfaces 5, 1902-1906 (2013).

96. J. D. Fan, C. Fábrega, R. R. Zamani, Y. Hao, and A. Parra, "Enhanced photovoltaic performance of nanowire dye-sensitized solar cells based on coaxial $\mathrm{TiO}_{2} @ \mathrm{TiO}$ heterostructures with a cobalt (II/III) redox electrolyte," ACS Appl. Mater. Interfaces 5, 9872-9877 (2013).

97. J. D. Fan, F. Guell, C. Fabrega, A. Shavel, and A. Carrete, "Enhancement of the photoelectrochemical properties of Cl-doped $\mathrm{ZnO}$ nanowires by tuning their coaxial doping profile," Appl. Phys. Lett. 99, 262102 (2011).

98. J. D. Fan, C. Fábrega, R. Zamani, A. Shavel, and F. Güell, "Solution-growth and optoelectronic properties of $\mathrm{ZnO}$ : Cl@ZnS core-shell nanowires with tunable shell thickness," J. Alloys Compd. 555, 213-218 (2013).

99. J. D. Fan, R. Zamani, C. Fábrega, A. Shavel, and C. Flox, "Solution-growth and optoelectronic performance of $\mathrm{ZnO}: \mathrm{Cl} / \mathrm{TiO}$ and $\mathrm{ZnO}: \mathrm{Cl} / \mathrm{Zn}_{\mathrm{x}} \mathrm{TiO}_{\mathrm{y}} / \mathrm{TiO}_{2}$ core-shell nanowires with tunable shell thickness," J. Phys. D 45, 415301 (2012).

100. K. Zhu, N. R. Neale, A. Miedaner, and A. J. Frank, "Enhanced charge-collection efficiencies and light scattering in dyesensitized solar cells using oriented $\mathrm{TiO}_{2}$ nanotubes arrays," Nano Lett. 7, 69-74 (2007).

101. J. P. González-Vázquez, V. Morales-Florez, and J. A. Anta, "How important is working with an ordered electrode to improve the charge collection efficiency in nanostructured solar cells?" J. Phys. Chem. Lett. 3, 386-393 (2012).

102. K. Tanaka, T. Takahashi, T. Ban, T. Kondo, and K. Uchida, "Extremely large binding energy of biexcitons in an organicinorganic quantum-well material $\left(\mathrm{C}_{4} \mathrm{H}_{9} \mathrm{NH}_{3}\right)_{2} \mathrm{PbBr}_{4}$," Solid State Commun. 127, 619-623 (2003).

103. C. Silvia, M. Edoardo, F. Paolo, L. Andrea, and G. Francesco " $\mathrm{MAPbI}_{3-\mathrm{x}} \mathrm{Cl}_{\mathrm{x}}$ mixed halide perovskite for hybrid solar cells: the role of chloride as dopant on the transport and structural properties," Chem. Mater. 25, 4613-4618 (2013).

104. K. N. Liang, D. B. Mitzi, and M. T. Prikas, "Synthesis and characterization of organic-inorganic perovskite thin films prepared using a versatile two-step dipping technique," Chem. Mater. 10, 403-411 (1998).

105. P. Langevin, "Recombinaison et mobilites des ions dans les gaz," Ann. Chim. Phys. 28, 433-530 (1903).

106. H. J. Snaith, "Estimating the maximum attainable efficiency in dye-sensitized solar cells," Adv. Funct. Mater. 20, 13-19 (2010). 